\title{
The Role of Stratigraphy in Growth Strata Studies: A Case Study of the Early Cretaceous Deposits in the Persian Gulf, SW Iran
}

\author{
Fereshth Ghaseminia1,2, Jahanbakhsh Daneshian ${ }^{3 *}$, Bahman Soleimany ${ }^{4}$, Massih Afghah ${ }^{1}$ \\ ${ }^{1}$ Department of Geology, Shiraz Branch, Islamic Azad University, Shiraz, Iran \\ ${ }^{2}$ Department of Geology, Fars Science and Research Branch, Islamic Azad University, Fars, Iran \\ ${ }^{3}$ Department of Geology, Kharazmi University, Tehran, Iran \\ ${ }^{4}$ Eeploration Directorate, N.I.O.C., Tehran, Iran \\ Email: Ghaseminia90@gmail.com, *Jdaneshian@yahoo.com, B_soleimany@yahoo.com, Massihafg2002@yahoo.com
}

How to cite this paper: Ghaseminia, F., Daneshian, J., Soleimany, B. and Afghah, M. (2016) The Role of Stratigraphy in Growth Strata Studies: A Case Study of the Early Cretaceous Deposits in the Persian Gulf, SW Iran. Open Journal of Geology, 6, 15131524.

http://dx.doi.org/10.4236/ojg.2016.612107

Received: August 31, 2016

Accepted: December 13, 2016

Published: December 16, 2016

Copyright $\odot 2016$ by authors and Scientific Research Publishing Inc. This work is licensed under the Creative Commons Attribution International License (CC BY 4.0).

http://creativecommons.org/licenses/by/4.0/

\section{Abstract}

The growth strata was investigated in the Early Cretaceous deposits including Fahliyan, Gadvan and Dariyan formations in the Well 3 that is located between QatarFars height and Hormuz Strait in Persian Gulf. This study is based on the lithostratigraphic analysis and microfossils distribution. Lithostratigraphically, the Well 3 is divided into three rock units including Fahliyan, Gadvan and Dariyan. Based on the microfossils content, the age of studied successions is Berriasian to Aptian. The comparison of seismic studies, lithostratigraphic analysis and microfossils distribution show that growth and generation of anticlines construct in the Early Cretaceous. As a result, the Fahliyan, Gadvan and Dariyan rock units have potential reservoir and oil trap.

\section{Keywords}

Growth Strata, Lithostratigraphy, Biostratigraphy, Seismic, Early Cretaceous, Persian Gulf

\section{Introduction}

The Early Cretaceous deposits in the Zagros basin and Persian Gulf have been divided into several rock units including Fahliyan, Gadvan, Dariyan and Kazhdumi formations [1]. The lithological diversity of the Early Cretaceous deposits shows unstable environmental conditions and active tectonic resulting from subduction of Arabian Plate beneath Iranian Plate [2] [3] [4]. In order to reconstruct tectonic process and paleogeo- 
graphic map of the Early Cretaceous deposits, lithostratigraphic and biostratigraphic studies have been performed. Investigation of lithostratigraphic characteristics of the Early Cretaceous deposits in the studied well is more effective in order to recognize source and reservoir rocks [5] [6]. The present study has focused on the growth strata in the Early Cretaceous deposits based on the lithostratigraphic characteristics, biostratigraphic analysis and seismic interpretations. The aim of performing growth strata is to investigate the tectonic transformations of the studied well [7] [8] [9]. Growth strata are deposits that are deposited concurrent with tectonic activities such as folding in an area and have an important status in formation of oil traps which have stratigraphicgeological structure. Indeed, folds can be a place for storing and accumulating oil and gas. When folding takes place in an area, concurrent with the growth of the structure of deposits, growth strata are deposited and these deposits are effective in dating the age of tectonic transformations [10] [11] [12].

In this research, stratigraphy and growth strata studies are combined for the first time. The results of this research can assist in detecting and identifying oil traps and their evolution along geological periods [13] [14]. For this purpose, the Early Cretaceous deposits have been investigated in one of the well in the Persian Gulf.

\section{Geological Setting}

The Zagros mountains in south west of Iran are considered as part of the Alpine-Himalaya Mountains [15] [16]. The Zagros mountains are located in northwest of the Persian Gulf and are affected by the Early Cretaceous to present Zagros orogeny. From the Middle Eocene to Early Miocene, the Arabian Plate began to impact with Central Iran and the Zagros belt orogeny is generated. The collision of the Arabic Plate and Zagros mountains is created the topography of the Persian Gulf [17] [18]. Persian Gulf is a marginal sea situated on continental shelf and its downhill is towards Oman Sea. Persian Gulf is $200-300 \mathrm{~km}$ wide and covered an area about 226,000 km². Morphologically, Persian Gulf is asymmetrical form and its slope is toward Arabic coast. The southern shore of the Persian Gulf consists of evaporation and tidal flat environments, while the northern shore comprises of hard and high rock units. The low-slope southern shore of the Persian Gulf and its shallow sea was formed anticlines with northern-southern trend like Saudi Arabia basement trend. The anticlines of Qatar, Roodkhan, and Bahrain have often constituted low-slope topography view controlled by fault systems. The northern shore of the Persian Gulf is clift shore with a north west trend and height of anticline reach to $1500 \mathrm{~m}$. Therefore, the northern shore structures of the Persian Gulf are different with southern shore structures, geometrically. Generally, the present deposits of the Persian Gulf become more fine-grained from the shore towards the depths. Currently, the deepest facies of the Persian Gulf is argillaceous limestone [19] [20]. Geologically, Persian Gulf is a shallow subduction formed during Neogene period in the southern margin of the Zagros mountains. The northern shore of the Persian Gulf has been folded by foldings of Pliocene-Pleistocene period. The main trend of the Persian Gulf is one of the geological consequences of the Zagros 
folding event formed during Pliocene-Pleistocene period. The studied well is located in the Persian Gulf between the heights of Qatar-Fars and Hormuz Strait (Figure 1).

\section{Materials and Methods}

The Early Cretaceous deposits in the Well 3 in the Persian Gulf were investigated. This well has been drilled and sampled by National Iranian Oil Company (NIOC). A total of 73 thin section were prepared and analyzed in order to determine lithostratigraphy, biostratigraphy and growth strata analysis. Thin sections were stained by potassium ferricyanide and alizarin-red S solution Biostratigraphic analysis are based on studies of [21] [22] [23]. Also, the frequency of the benthic microfossils was determined. The boundary between formations were determined by lithostratigraphic characteristics and microfossil distribution, and then growth strata of deposites was studied. The study method of growth strata is based on In-line study and also flatted of headformations by Karizma application. After the operation of seismic processing, the interpretation of seismic data was started. This operation requires thorough examination of the data and the results of operations and can require seismic lines. The most obvious characteristics of the Karizma application is the show of data into spectrum the application to is designed to display seismic lines recorded by the receivers used in seismic survey and is able to display two-dimensional seismic lines into three-dimensional lines form. This means that the application takes the received records by a straight line receiver (Inline or crossline) and to the then shows ups and downs (peak and trough) which indicates a change in flank and its direction Growth strata of the Early Cretaceous deposits were recognized by the determination of thickness difference of headformations.

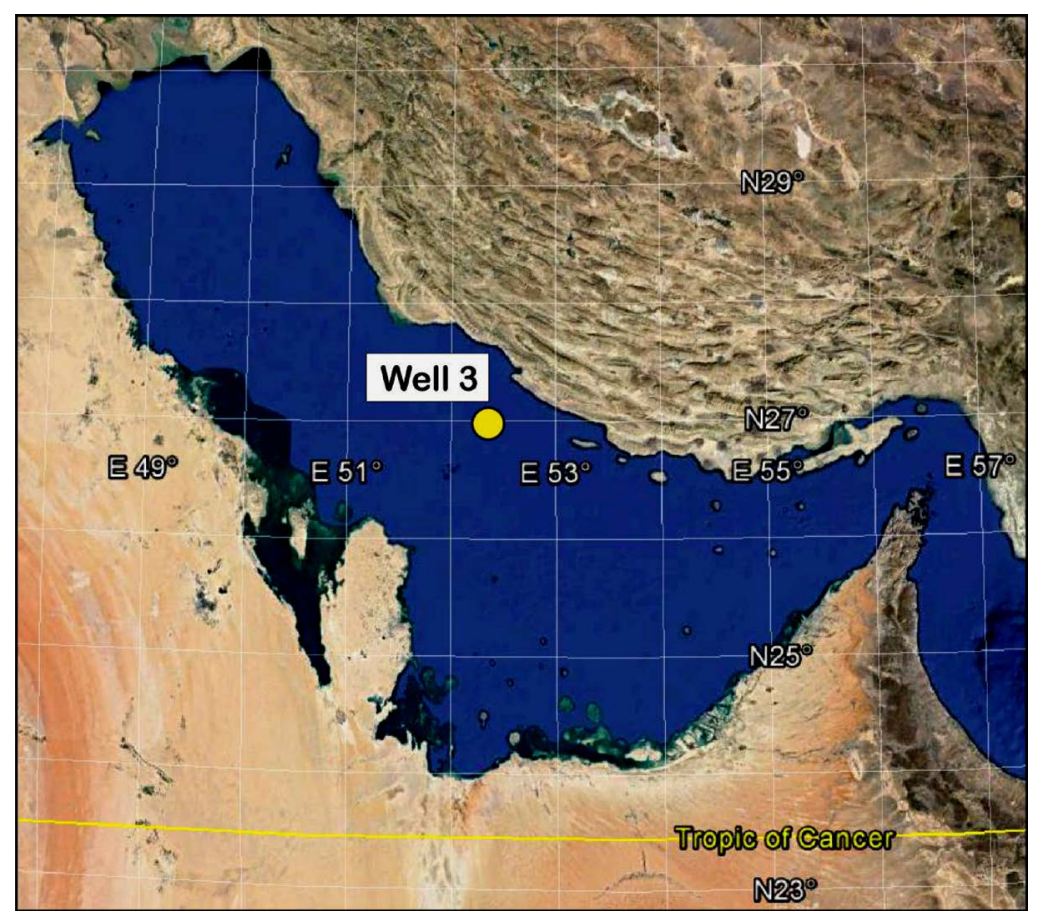

Figure 1. The geographical position of the Well 3 in the Persian Gulf, south west of Iran. 


\subsection{Lithostratigraphy}

The drilled thickness in the Well 3 is 2220 m and consists of the Surgah to Kangan formations. The Early Cretaceous deposits with $365 \mathrm{~m}$ in this well consist of Fahliyan, Gadvan and Dariyan formations. The thickness of the Fahliyan Formation is $172 \mathrm{~m}$ and lithostratigraphically consists of limestone, shale, sandstone and dolomite. The thickness of the Gadvan Formation is $81 \mathrm{~m}$ and lithostratigraphically consists of limestone and dolomite. Also, the thickness of Dariyan Formation is $112 \mathrm{~m}$ and lithostratigraphically consists of argillaceous limestone, shale and dolomite.

\subsection{Biostratigraphy}

The biostratigraphic framework of the Early Cretaceous deposits in south west of Iran studied by Wynd. Wynd has introduced 1 Facies, 6 Assemblage zones, and 1 Subzone in the Early Cretaceous deposits in south west of Iran and summarized them in Table 1. Biostratigraphic studies led to recognition of 3 species belonging 11 genera of benthic foraminifera in the studied well. Based on the recognized fossil in the Early Cretaceous deposits, two biozones were identified in the Falyian and Dariyan formations and these biozones were adaptable with biozone 14 and 16 indicated by Wynd. The distribution of benthic foraminifera and algaes has been plotted on the biostratigraphic column (Figure 2). Most of recognized fossils were destroyed by diagenetic process. Due to absence of index microfossils and dolomitization process, no biozone was identified in the Gadvan Formation. The following assemblages were identified for this study:

\subsubsection{Pseudocyclammina lituus-Trocholina Assemblage Zone (No.14)}

This assemblage zone is identified in the Fahliyan Formation and is marked by the presence of benthic foraminifera such as Pseudocyclammina lituus, Trocholina arabica,

Table 1. Biostratigraphy scheme of the early cretaceous deposits in south west of Iran identified by Wynd (1965).

\begin{tabular}{cccc}
\hline Age & Geographical extension & Stratigraphic position & Biozone \\
Tithonian-Neocomian & Fars region & $\begin{array}{c}\text { The most upper part of the Surmeh Formation } \\
\text { and the base of Fahliyan Formation }\end{array}$ & $\begin{array}{c}\text { Calpionella-spicules assemblage zone } \\
\text { (No.11) }\end{array}$ \\
Neocomian-Albian & Lorestan region & The lower part of the Sarvak and Garu \\
formations & Radiolaria flood facies (No.12)
\end{tabular}




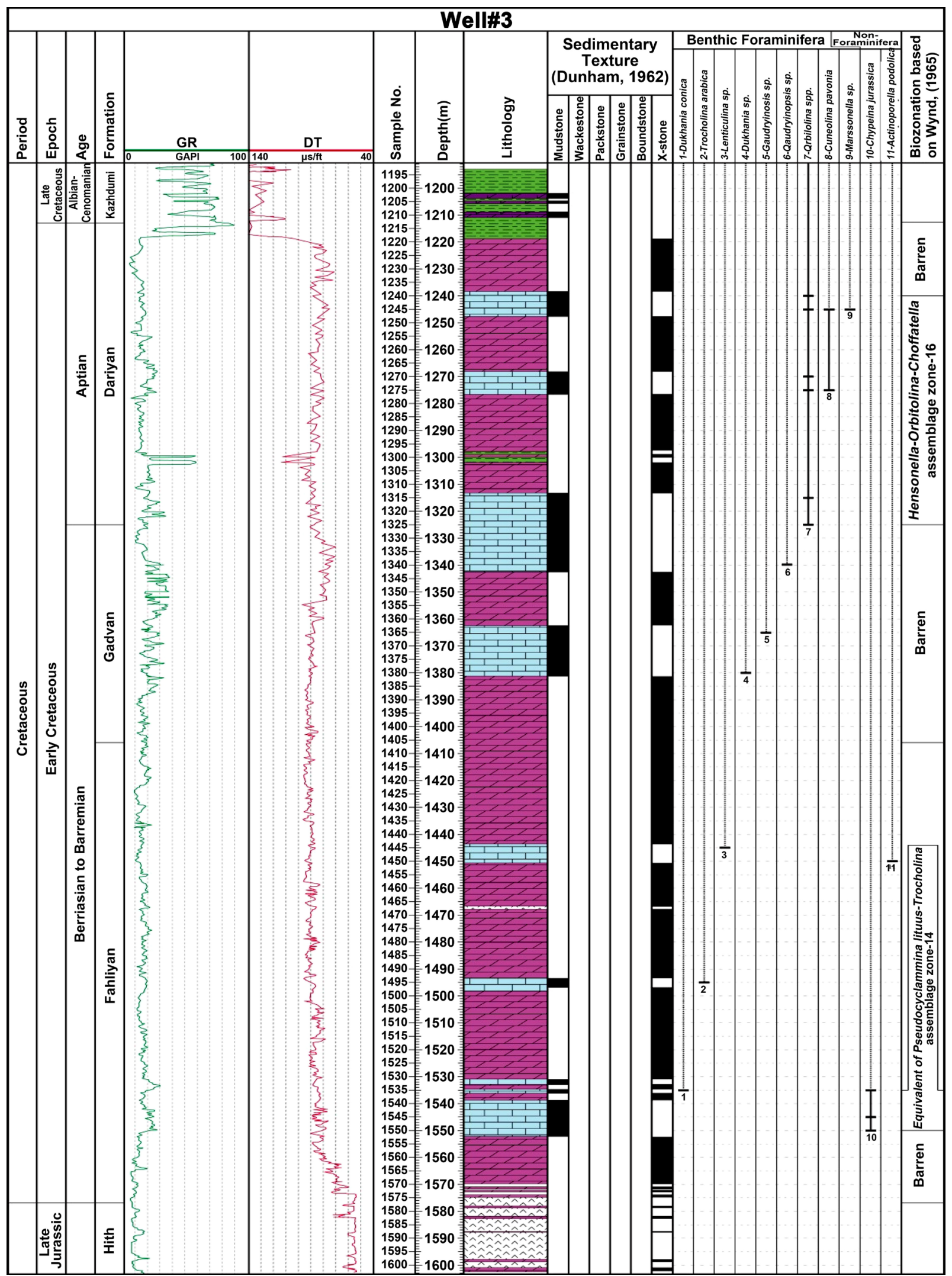

Figure 2. Lithostratigraphic and biostratigraphic column of the Early Cretaceous deposits in the well No.3, Persian Gulf, south west of Iran. 
Trocholina spp., Nautiloculina oolithica, Dukhania conica, Gaudryinopsis sp., Lenticulina sp., Quasispiroplectammina sp. and algaes such as Salpingoporella muhlbergi, Salpingoporella annulata, Actinoporella podolica, Polygonella incrustata, Lithocodiuma aggregatum and Clypeina jurassica. This assemblage indicates the Pseudocyclammina lituus-Trocholina assemblage zone of Wynd. The thickness of this assemblage zone is $15 \mathrm{~m}$ (From 1535 to $1550 \mathrm{~m}$ ) and its age is assigned to Berriasian-Barremian.

\subsubsection{Hensonella-Orbitolina-Choffatella Assemblage Zone (No.16)}

This assemblage zone is identified in the Dariyan Formation and is marked by the presence of benthic foraminifera such as Hensonella cylindrica, Orbitolina spp., Choffatella sp., Cuneolina pavonia, Nautiloculina sp., Marssonella sp., Dukhania sp., Gaudryinopsis sp., Cyclamminids, Nezzazata sp., miliolids, rotaliids, and algaes such as Lithocodium aggregatum, Acicularia sp. This assemblage represents the HensonellaOrbitolina-Choffatella assemblage zone of Wynd. The thickness of this assemblage zone is $85 \mathrm{~m}$ (From 1240 to $1325 \mathrm{~m}$ ) and its age is assigned to Aptian.

Due to lack of index microfossils and Widespread dolomitization in the Gadvan Formation, no biozone has been introduced in this formation. Examples of the genera and species of benthic foraminifera and algaes were shown in Figure 3.

\section{Discussion}

The growth strata studies is based on lithostratigraphic characteristics and stratigraphic distribution of microfossils in the studied well. In this way, the headformations are recognized by the obtained information from lithostratigraphic and biostratigraphic analysis and seismic information. So far, numerous oil fields have been detected in the Persian Gulf and most of these oil fields are explorated in the anticline structures. The growth strata studies is very important in identifying these oil traps. One of the different types of oil traps is folded type which has various subtypes. First subtype, are formed under the influence of compressional force and eventually folding. Second, they are developed in response to the difference between compressional deposits, and finally, is related to diapiric process [24] [25] [26] [27]. The first type or anticline traps are result of compressional forces and is formed in regions such as active margins of continents where the crust undergoes shortening [25] [28] [29] [30]. In the Zagros Basin and Persian Gulf regions, different types of anticline traps are recognized. Tectonic activities are most important in making oil traps and lead to folding of deposits. For this reason, the deposits are divided into three groups based on these activities [26] [31] [32] [33]. (I) Pertectonic: these deposits are initial deposition in basins and are usually formed in response to factors such as weathering and erosion and then transfer to basin such as seas and lakes. The most important characteristic of these deposits are their equal thickness. (II) Syntectonic: these deposits are usually settled in basins concordant with tectonic activities [27] [34], and greatly assist in interpretation of the tectonic activities in the area. Also, these deposits are more important in dating the age of tectonic activities. These types of deposits are known as growth strata if they are related to tectonic phenomena such as folding [28] [35]. The growth strata in anticlines are recog- 
nized with characteristics such as variable thickness, fanning form, and alteration of the slope from edge to the top. (III) Posttectonic: these deposits are usually formed following tectonic activities in the basins. The thickness of these deposits are absolutely equal, and are deposited in the basins following extension or pressure. During the formation of an anticline in response to compressional forces concordant to deposotion, the growth strata was formed in the sides of anticline. The thickness of these deposits decreases from the side towards the top of the anticline and shows growth and formation of the anticline [29] [36] [37]. To investigate the growth strata in the studied well, first the In-line is identified (horizontal line used in interpretation of seismic information of an anticline structure) and then with using the In-line study, the growth strata is identified in the intervals between Hith and Dariyan formations (Figure 4) [38].
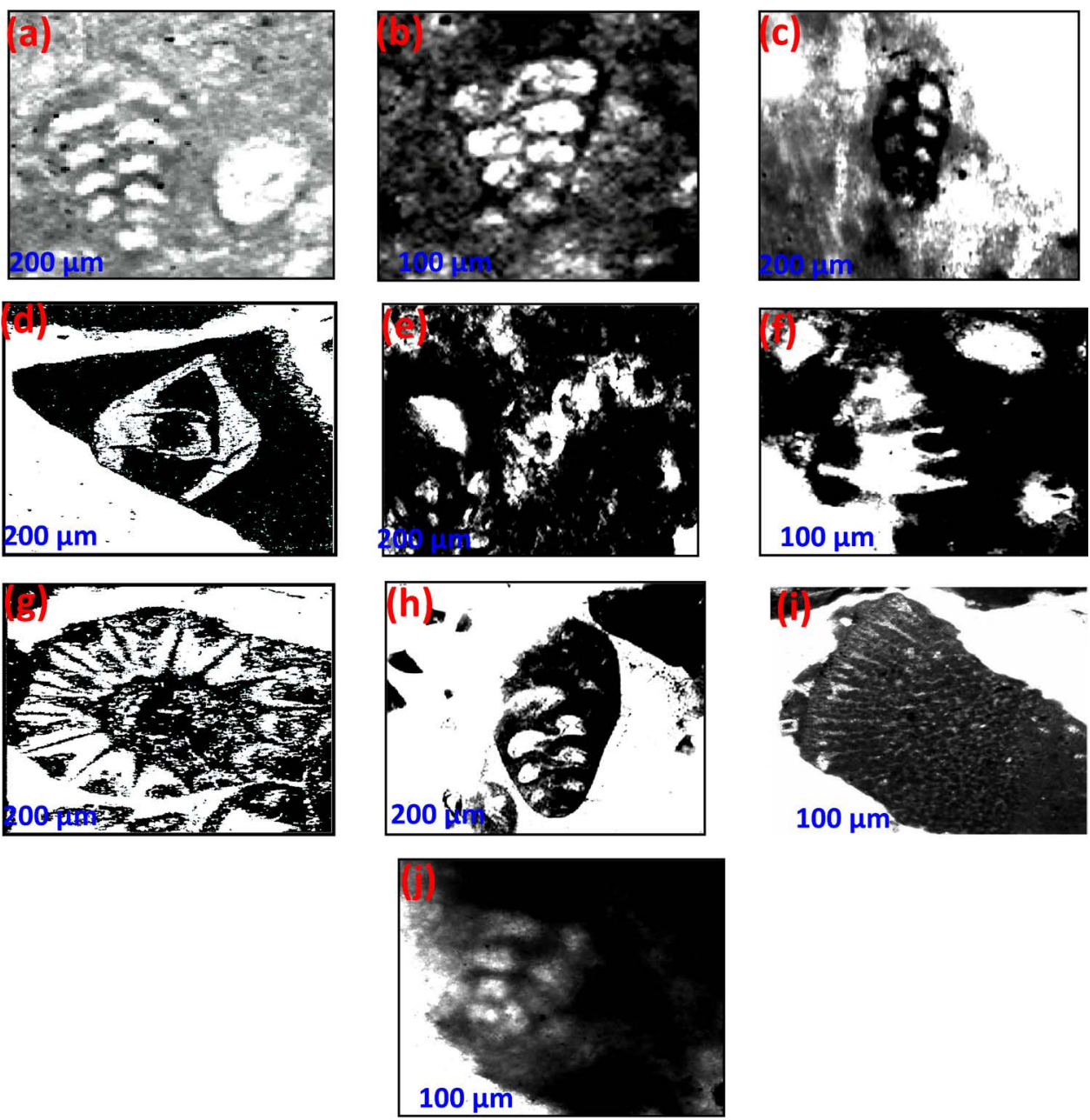

Figure 3. Examples of recognized benthic foraminifera and algaes in the well No. 3, Persian Gulf, south west of Iran. (a) Cuneolina pavonia d'Orbigny (Fahlyian Formation); (b) Marssonella sp. (Daryian Formation); (c) Gaudryinopsis sp. (Gadvan Formation); (d) Lenticulina sp. (Fahlyian Formation); (e) Actinoporella podolica (Fahlyian Formation); (f) Trocholina arabica Paalzow (Fahlyian Formation); (g) Clypeina jurassica Faver\& Richar (Fahlyian Formation); (h) Dukhania conica Henson (Fahlyian Formation); (i) Orbitolina sp. (Daryian Formation); (j) Quasispiroplectammina sp. (Gadvan Formation). 


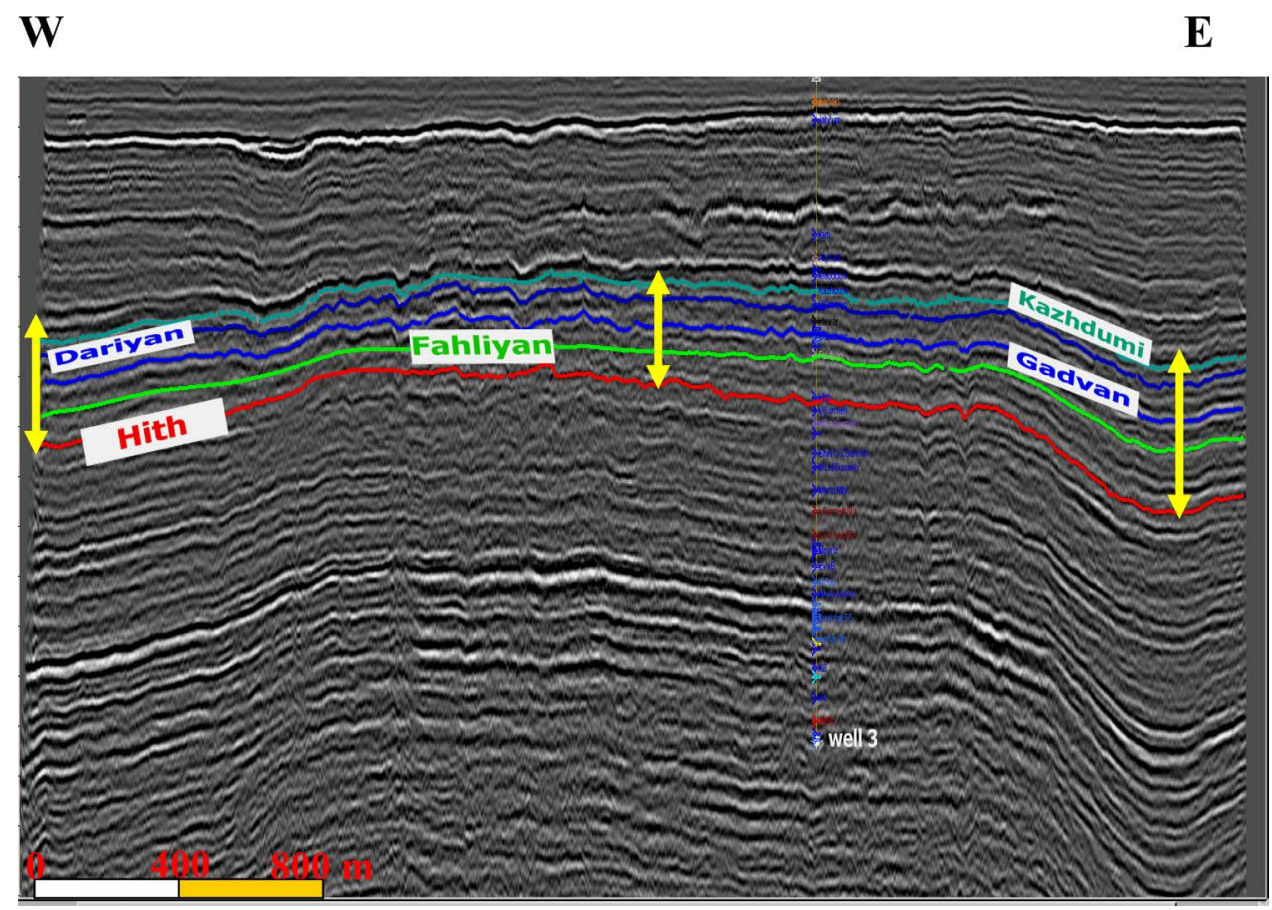

Figure 4. Seismic interpretation of studied well together with the information of studied headformations.

The difference in thickness between the Hith and Dariyan formations was determined in the edges and head of the structure considering the seismic interpretation and headformations data obtained from lithostratigraphy and stratigraphic distribution of microfossils. This difference in the thickness of deposition is observed from the edge towards the head of the structure and it decreases toward the head. The deposits that are settled during the Early Cretaceous in studied well represent growth of the structure at this period. The thickness of the studied formations at their edge parts suggests growth strata deposits that settled concurrent with generation of the structure. In the next stage, based on flatting of each horizon onto the determined headformations in the studied well, the growth strata analysis was performed. Indeed, variations in deposition at different geological periods are specified by flatting on every horizon or headformation. The difference in thickness between the Hith and Dariyan formations are observed by flattening on Fahliyan and Dariyan horizons (Figure 5, Figure 6). In these intervals, the thickness difference of deposits from the side towards the head of the structure suggests deposition of growth strata in the structure's edges during the Early Cretaceous period.

\section{Conclusion}

This study is assigned to lithostratigraphic and biostratigraphic analysis of the Early Cretaceous deposits in Persian Gulf. Lithostratigraphically, the deposits of Early Cretaceous in Persian Gulf consist of limestone, argillaceous limestone, shale, sandstone and dolomite. The biostratigraphic analysis based on benthic foraminifera led to recognition 


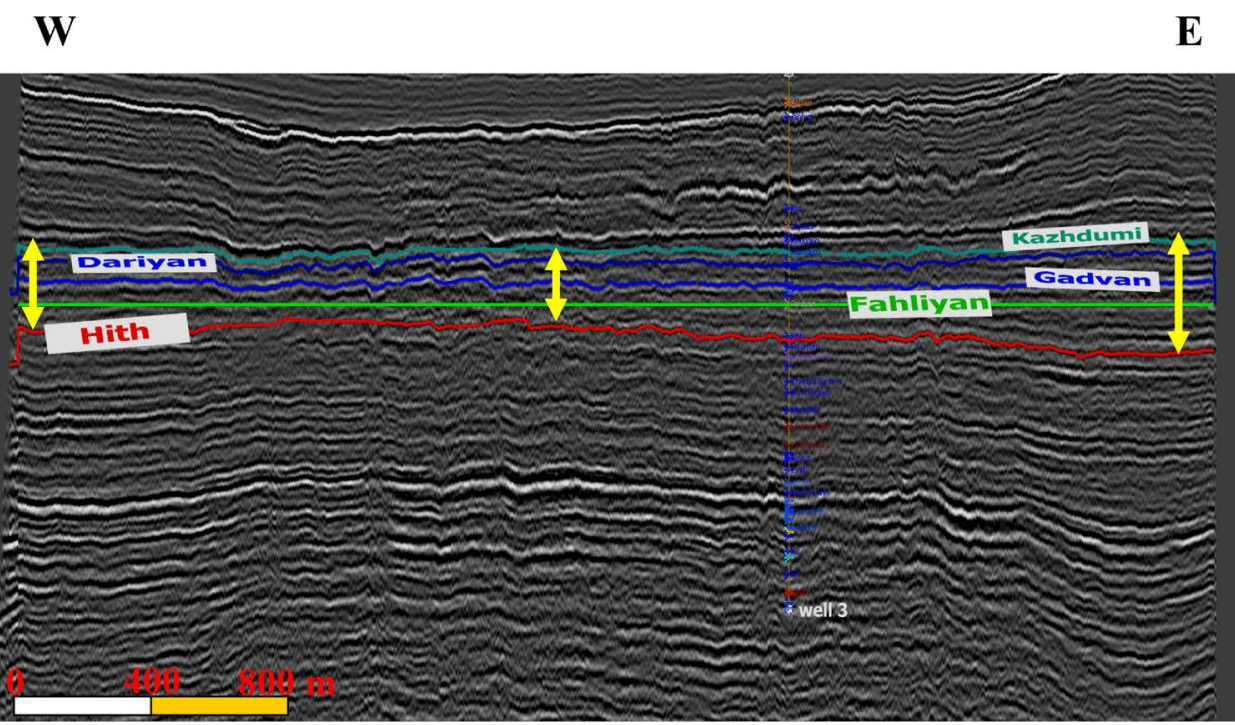

Figure 5. Flatting on the Fahliyan horizon in the studied well.

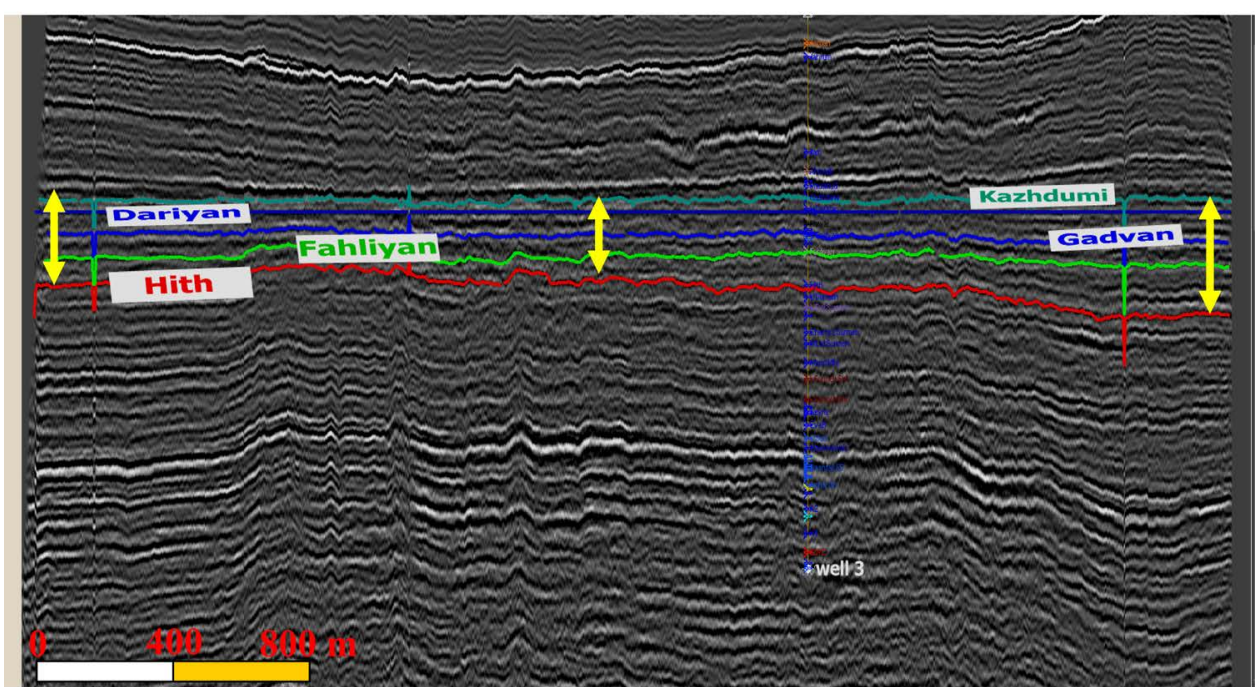

Figure 6. Flatting on the Dariyan horizon in the studied well.

of two assemblage zones that are adoptable with biozones indicated by Wynd. These biozones are Pseudocyclammina lituus-Trocholina assemblage zone (No.14) and Hensonella-Orbitolina-Choffatella assemblage zone (No.16). The age of studied formations based on identified biozones is assigned to Berriasian-Aptian. In this research, stratigraphy and growth strata studies are combined for the first time. The results of this research can assist in detecting and identifying oil traps and their evolution along geological periods. In order to growth strata analysis, first by specifying the lithostratigraphic status and stratigraphic development of microfossils of the studied subsurface section and using their data for correspondence with what has been obtained based on the seismic interpretation of the well of interest, they were compared so that the position and situation of horizons or headformations are accurately determined. Following de- 
termination of precise boundaries of every formation, the growth strata of these deposits were studied. By determining the thickness difference in the specified parts, the growth strata in the Early Cretaceous period in the studied region have been recognized. As a result, the generation of the structure has taken place within the Early Cretaceous deposits.

\section{References}

[1] James, G.A. and Wynd, J.G. (1965) Stratigraphic Nomenclature of Iranian Oil Consortium Agreement Area. AAPG Bulletin, 49, 2182-2245.

[2] Takin, M. (1972) Iranian Geology and Continental Drift in the Middle East. Nature, 235, 147-150. https://doi.org/10.1038/235147a0

[3] Alavi, M. (1994) Tectonics of the Zagros Orogenic Belt of Iran; New Data and Interpretations. Tectonophysics, 229, 211-238. https://doi.org/10.1016/0040-1951(94)90030-2

[4] Berberian, M. and King, G.C.P. (1981) Towards a Paleogeography and Tectonic Evolution of Iran. Canadian Journal of Earth Sciences, 18, 210-265. https://doi.org/10.1139/e81-019

[5] Gollesstaneh, A. (1965) Micropalaeontological Study of the Upper Jurassic and Lower Cretaceous of Southern Iran. Unpublished Ph.D. Thesis, University College, London, 629 p.

[6] Wynd, J. (1965) Biofacies of Iranian Oil Consortium Agreement Area. IOOC Report 1082 (Unpublished).

[7] Kalantari, A. (1975) Microbiostratigraphy of the Sarvestan Area Southwestern Iran. N.O.C. Geological Laboratories Publication, Vol. 5, 26.

[8] Kheradpir, A. (1975) Stratigraphy of Khami Group in Southwest Iran. O.S.C. Report, 1235.

[9] Afghah, M. (2006) Microbiostratigraphy of Fahliyan Formation in Kuhe-e-Gadavan and AbSiah. JSIA $U, 61,89-107$.

[10] Hosseini, A. and Conrad, M. (2008) Calcareous Algae, Foraminifera and Sequence Stratigraphy of the Fahliyan Formation at Kuh-e-Surmeh. Geologia Croatica, 61, 215-237.

[11] Mosadegh, H. and Parvaneh Nejad Shirazi, M. (2009) Algal Biozonation of Fahliyan Formation (Neocomian) in the Zagros Basin, Iran. European Geoscience Union, Geophysical Research Abstracts, EGU 2009-8507, 11:1.

[12] Adabi, M.H., Salehi, M.A. and Ghabeishavi, A. (2010) Depositional Environment, Sequence Stratigraphy and Geochemistry of Lower Cretaceous Carbonates (Fahliyan Formation), South-West Iran. Journal of Asian Earth Sciences, 39, 148-160. https://doi.org/10.1016/j.jseaes.2010.03.011

[13] Feghhi, A. (2010) Study of Microfacies and Sequence Stratigraphy of Fahlyian Formation in Marun Oil Field, Southwest Iran. Master Thesis, Science at the University of Petroleum University of Technology Exploration and Production Department Tehran, Tehran, 83 p.

[14] Jamalian, M., Adabi, M.A., Moussavi, M.H., Sadeghi, A., Baghbani, D. and Ariyafar, B. (2010) Facies Characteristic and Paleoenvironmental Reconstruction of the Fahliyan Formation, Lower Cretaceous, in the Kuh-e Siah Area, Zagros Basin, Southern Iran. Facies, 57, 101-122. https://doi.org/10.1007/s10347-010-0231-3

[15] Lasemi, Y. and Feyzi, M. (2007) Platform and Off-Platform Facies of Fahliyan Formation: Evidence for Intrashelfbasin in Southwest of Iran. 25th Symposium of Geology, Geological Survey of Iran, 84-85. (In Persian)

[16] Maleki, S. and Lasemi, L. (2011) Sedimentary Environment Sequence Stratigraphy of the Fahliyan Formation in Assaluyeh (Bidkhon) and Khartang Sections, Southwest Iran. Jour- 
nal of Basic and Applied Scientific Research, 1, 2641-2647.

[17] Abyat, A., Baghbani, D., Afghah, M., Kohansal Ghadimvand, N. and Feghi, A. (2012) Microbiostratigraphy and Lithostratigraphy of Fahiyan and Gadvan Formations in Kuhe-eSurmeh (Zagros Basin, South West Iran). Advances in Environmental Biology, 6, 145-164.

[18] Afghah, M. and Shaabanpour Haghigh, A. (2014) Aptian Biostratigraphy in South Zagros Basin, Southwest Iran. Geoscience Frontiers, 5, 277-288. https://doi.org/10.1016/j.gsf.2013.07.001

[19] Abyat, A., Baghbani, D., Afghah, M. and Kohansal Ghadimvand, N. (2014) Microfacies, Depositional Environment and Sequence Stratigraphy of the Fahliyan and Gadvan Formation, Kuh-e-Surmeh Section (Zagros Basin, Southwest Iran). Himalayan Geology, 35, 82-89.

[20] Abyat, A., Baghbani, D., Afghah, M., Kohansal Ghadimvand, N. and Afsari, S. (2016) Neocomian-Barremian Foraminifers and Algae from Coastal Fars (South Iran). Arabian Journal of Geosciences, 9, 262. https://doi.org/10.1007/s12517-015-2128-5

[21] Afghah, M., Abtahiyan, A. and Saberi, A. (2016) Foraminiferal Biostratigraphy of Early Crestaceous (Hauterivian-Barremian) Sediments of the Zagros Basin (SW of Iran). Journal of African Earth Sciences, 121, 42-55. https://doi.org/10.1016/j.jafrearsci.2016.05.010

[22] Soleimany, B. and Sabat, F. (2010) Style and Age of Deformation in the NW Persian Gulf. Petroleum Geoscience, 16, 31-39. https://doi.org/10.1144/1354-079309-837

[23] Soleimany, B. (2010) Reactivation of Deep Seated Folds in Northwest Persian Gulf. 219 p.

[24] Alavi, M. (2004) Regional Stratigraphy of the Zagros Fold-and-Thrust Belt of Iran and Its Prof Orland Evolution. American Journal of Science, 304, 1-20. https://doi.org/10.2475/ajs.304.1.1

[25] Alavi, M. (2007) Structures of the Zagros Fold-Thrust Belt in Iran. American Journal of Science, 307, 1064-1095. https://doi.org/10.2475/09.2007.02

[26] Stocklin, J. (1968) Structural History and Tectonics of Iran: A Review. AAPG Bulletin, 52, 1229-1258.

[27] Bak, R., Behbahany, A. and Challani, N. (2016) Marin Geology in the Persian Gulf. 374 p.

[28] Kalantari, A. (1976) Microbiostratigraphy of Sarvestan Area, Southwestern Iran. National Iranian Oil Company Publications, Vol. 5, 1-52.

[29] Loeblich Jr., A.R. and Tappan, H. (1988) Foraminiferal Genera and Their Classification. Springer, New York, 970 p. https://doi.org/10.1007/978-1-4899-5760-3

[30] Dragstan, O. (1982) Lower Cretaceous Marine Algae and Calpionellida from Canada (Sanpedro)-Asturisa Province (Spain). Cuadernos Geologia Iberica, 8, 125-143.

[31] Dragstan, O. (1999) Early Cretaceous Algae of Aliman (South Dobrogea): A Revision and Description of Two New Species from East Carpathians. Acta Paleontologica Romaniae, 2, 125-137.

[32] Deini, I. and Radoicic, R. (1999) Cleypeina dragsrani sp. nov., Salpingoporella granieri sp. Nov., and Other Dasycladaean algae from the Bereiasain of Easten Saridinia. Acta Paleontologica Romaniae, 2, 105-123.

[33] Husinec, A. and Sokac, B. (2006) Early Cretaceous Benthic Associations (Foraminifera and Calcareous Algae) of a Shallow Tropical-Water Platform Environment (Mljet Island, Southern Croatia). Cretaceous Research, 27, 418-441. https://doi.org/10.1016/j.cretres.2005.07.008

[34] Schroeder, R., Frans S.P., Van Buchem, F., CHerachi, A., Baghbani, D., Vincent, B., Immenhauser, A. and Granier, B. (2010) Resived Orbitolinid Biostratigraphic Zonation for the Barremian-Aptian of the Eastern Arabian Plate and Implications for Reginal Stratigraphic 
Correlations. GeoArabia, 4, 49-96.

[35] Schlagintweit, F. (2015) Taxonomic Review of Some Late Jurassic-Early Cretaceous Benthic Foraminifera Established by Gollesta Neh (1965) from the Zagros Fold and Thrust Belt of Iran. Acta Palaenologica Romaniae, 9, 27-31.

[36] Omana, L., Miranda-Aviles, R. and Jesus Puy-Alquiza, M. (2015) Berriasian-Early Valanginian Calcareous Shallow-Water Facies the Arperos Basin: A Proposal from the Foraminiferal Assemblage of the Clasts of the Guanajuato Conglomerate, Central Mexico. Boletin de la Sociedad Geologica Mexicana, 67, 45-57.

[37] Rezaei, M.R. (2006) Oil Geology. Tehran University Publication, Tehran, 410 p.

[38] Poblet, M., Bulnes, M., McClay, K. and Hardy, S. (2004) Structural Relief and Fold Area versus Shortening: A Graphical Technique to Unravel the Kinematics of Thrust-Vetated Folds. In: McClay, K., Eds., Thrust Tectonics and Hydrocarbon Systems, American Association of Petroleum Geologists Memoir, Vol. 82, 372-399.

Submit or recommend next manuscript to SCIRP and we will provide best service for you:

Accepting pre-submission inquiries through Email, Facebook, LinkedIn, Twitter, etc.

A wide selection of journals (inclusive of 9 subjects, more than 200 journals)

Providing 24-hour high-quality service

User-friendly online submission system

Fair and swift peer-review system

Efficient typesetting and proofreading procedure

Display of the result of downloads and visits, as well as the number of cited articles

Maximum dissemination of your research work

Submit your manuscript at: http://papersubmission.scirp.org/

Or contact ojg@scirp.org 